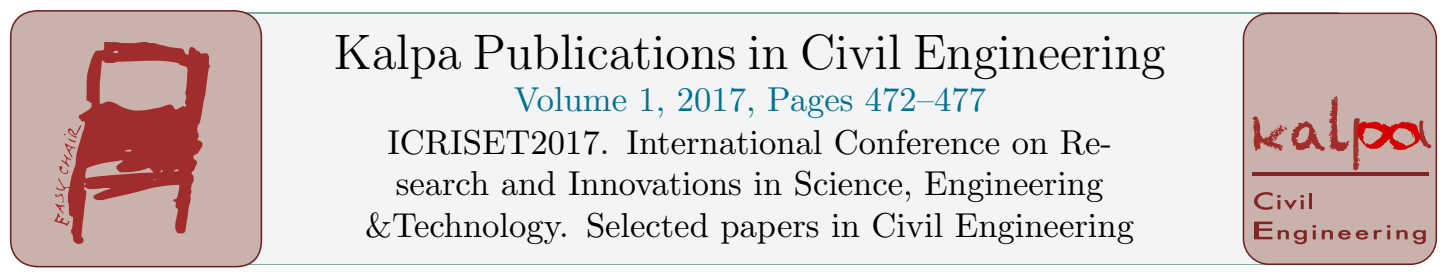

\title{
Effect of Explosive Distance on Hyperbolic Cooling Tower
}

\author{
Pooja N. Shah ${ }^{1,2 *}$ and Dipali Y. Patel ${ }^{1 \dagger}$ \\ ${ }^{1}$ Civil Engineering Department, \\ ${ }^{2}$ Chandubhai S. Patel Institute of Technology, (CHARUSAT), Changa, Gujarat, India \\ shahpooja131093@gmail.com, dipalipatel.cveCharusat.ac.in
}

\begin{abstract}
Cooling towers are designed to handle the heat rejected from the power plant by keeping it cool without damaging the whole structure. These are the large structures with small thickness. An attempt has been made to study the effect of blast load on cooling tower. Cooling tower has been analysed for blast load assuming fixity at base. The blast pressure is calculated using IS 4991:1968. Variable explosive distances has been taken to study the behaviour of structure. Structure is modelled and analysed in ANSYS 16.2. The effect of blast load has been analysed in terms of deflection, stresses and strain.
\end{abstract}

\section{Introduction}

Cooling towers are designed to keep the equipment cool enough to operate efficiently without damaging the structure and without effecting the whole power plant. The hyperbolic shape of the cooling tower is more beneficial as it has more strength and stability including large available area at the base due to the shape.

As it is a part of a power plants it is affected by both static and dynamic loads. Blast can also occur in power plant and effect of that is also a predominant part of the analysis. Explosion can be defined as a sudden release of an energy. The effect of explosion on the structure is dependent on the "Blast Wave". Blast parameters and calculation of blast pressure are given in IS 4991:1968.

Murali et al. (2012) has worked on response of cooling towers to wind loads by assuming fixity at base. They compared membrane forces and bending moments for three different geometry of cooling tower and has given normalized curves for that.

Many people have been worked on this structure for earthquake load, wind load etc. to observe the behaviour of the cooling tower. No one has attempted to analyse the cooling tower for blast load. Here, I have made an attempt to perceive the effect of blast load on hyperbolic cooling tower. 


\section{Modelling of Hyperbolic cooling tower}

The considered geometry of Cooling tower is shown in table 1 and the parameters are as per Table 1. The cooling tower is fixed at base. Modelling of cooling tower has been done using ANSYS 16.2 .

\begin{tabular}{|r|c|c|c|}
\hline Sr no. & Description & Symbol & Parametric value(m) \\
\hline 1 & Total height & $\mathrm{H}$ & 122 \\
\hline 2 & Height of throat & $\mathrm{H}_{\mathrm{thr}}$ & 98.26 \\
\hline 3 & Diameter at top & $\mathrm{D}_{\mathrm{t}}$ & 55.07 \\
\hline 4 & Diameter at base & $\mathrm{D}_{\mathrm{b}}$ & 56.58 \\
\hline 5 & Diameter at throat level & $\mathrm{D}_{\mathrm{thr}}$ & 50.6 \\
\hline
\end{tabular}

Table 1 : parameters of cooling tower

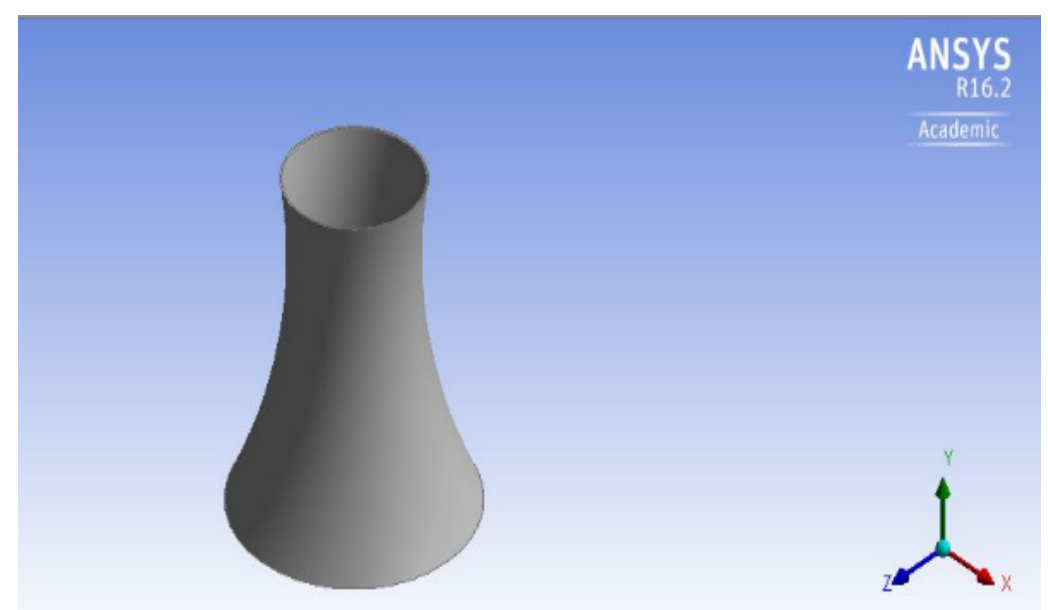

Figure 1 : Model of cooling tower for the geometry of present study

\section{Equations for calculation of blast load}

The previous work of blast load on building show the following equations for the calculation. The same is also given in IS 4991:1968. Many of the equations are same but in IS code they are given in simplified form of tables so the codal provisions are taken into consideration.

The valuations of peak overpressure due to blast based on scaled distance $Z=R / W^{1 / 3}$ was presented by Brode (1955) as:

$$
\begin{gathered}
P_{s o}=\frac{6.7}{Z^{3}}+1 \text { bar }\left(P_{\text {so }}>10 \text { bar }\right) \\
P_{\text {so }}=\frac{0.975}{Z}+\frac{1.455}{Z^{2}}+\frac{5.85}{Z^{3}}-0.019 \operatorname{bar}\left(0.1<P_{\text {so }}<10 \mathrm{bar}\right)
\end{gathered}
$$

Hansen and Newmark (1961) has given and equation to evaluate the maximum blast pressure (Pso), for explosion at ground surface. 


$$
P_{s o}=6784 \mathrm{~W} / R^{3}+93\left(W / R^{3}\right)^{1 / 2}
$$

Mills (1987) has introduced an expression,

$$
P_{\text {so }}=1772 / Z^{3}-114 / Z^{2}+108 / Z
$$

The value of Pso is given in table 1 in IS 4991:1968.

The Blastwave spreads through the environment. The air behind the shock front is moving in outer direction at the decreased speed. The speed of the air particles, and thus the wind pressure, relies upon the peak overpressure of the Blastwave. The dynamic pressure $q(t)$ is connected with speed. Blastwave front speed equation Us and the maximum dynamic pressure qs, are characterized as:

$$
\begin{gathered}
U_{s}=a_{0} \sqrt{\frac{6 p_{s}+7 p_{0}}{7 p_{0}}} \\
q_{s}=\frac{5 p_{s}^{2}}{2 \cdot\left(p_{s}+7 p_{0}\right)}
\end{gathered}
$$

Where: ps - peak static overpressure in bar,

$$
\begin{aligned}
& \mathrm{p} 0 \text { - ambient air pressure in bar } \\
& \mathrm{a} 0 \text { - sound speed in the air in } \mathrm{m} / \mathrm{s} \text {. }
\end{aligned}
$$

Maximum reflected pressure $\mathrm{Pr}$

$$
P_{r}=2 P_{s o}\left\{\frac{7 P_{o}+4 P_{s o}}{7 P_{o}+P_{s o}}\right\}
$$

Reflected impulse $i_{r}=\frac{1}{2} P_{r} t_{d}$

The reflected over pressure which drops from the peak value Pro to over pressure in clearance time tc given by:

$t_{c}=\frac{3 S}{U}$ or $t_{d}$ Whichever is less

Where, $\mathrm{S}=\mathrm{H}$ or $\mathrm{B} / 2$ whichever is less

$\mathrm{U}=$ shock front velocity

\section{Analysis of blast load}

\subsection{Design parameters for blast calculations}

For detonation of a 1 tonne explosive, Blast parameters are evaluated on an above structure, situated at $15 \mathrm{~m}$ from ground zero.

For that scaled distance is $15 \mathrm{~m}$ and various design parameters for the calculation of blast load has been taken from the code IS 4991:1968, 


$$
\begin{array}{ll}
\checkmark & \mathrm{P}_{\mathrm{so}}=8 \mathrm{~kg} / \mathrm{cm}^{2} \\
\checkmark & \mathrm{P}_{\mathrm{ro}}=41.60 \mathrm{~kg} / \mathrm{cm}^{2} \\
\checkmark & \mathrm{q}_{\mathrm{o}}=10.667 \mathrm{~kg} / \mathrm{cm}^{2} \\
\checkmark & \mathrm{t}_{\mathrm{o}}=9.50 *(1)^{1 / 3}=9.50 \text { milliseconds } \\
\checkmark & \mathrm{t}_{\mathrm{d}}=5.39 *(1)^{1 / 3}=5.39 \text { milliseconds }
\end{array}
$$

The pressure due to blast is $P_{s o}+C_{d} q_{o}=20.8004 \mathrm{~kg} / \mathrm{cm}^{2}=2.0384392 \mathrm{MPa}$.

This same method has been followed for the actual distance of the explosion $30 \mathrm{~m}, 60 \mathrm{~m}$ and $90 \mathrm{~m}$ from the structure.

\subsection{Material property}

Density: $2500 \mathrm{~kg} / \mathrm{m} 3$

Poisson's ratio: 0.18

Young's modulus: 2.85 x $104 \mathrm{MPa}$.

\subsection{Blast analysis}

The blast study has been completed for fixed base cooling tower and the modelling and analysis has been carried out using ANSYS 16.2.

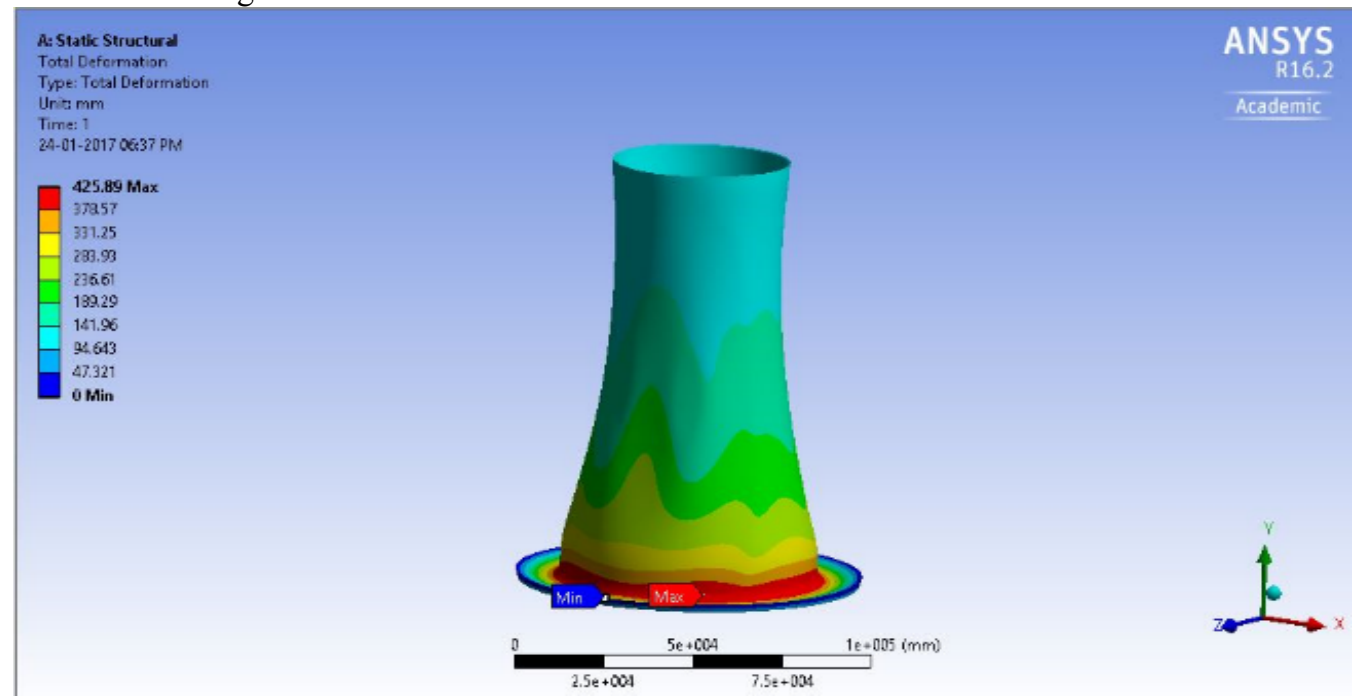

Figure 2 : Deformation of cooling tower

\subsection{Analysis results}

\begin{tabular}{|c|c|c|c|c|}
\hline $\begin{array}{c}\text { Actual } \\
\text { distance(m) }\end{array}$ & $\mathbf{1 5}$ & $\mathbf{3 0}$ & $\mathbf{6 0}$ & $\mathbf{9 0}$ \\
\hline $\begin{array}{c}\text { Total } \\
\text { deformation } \\
(\mathbf{m m})\end{array}$ & 425.89 & 42.99 & 9.5126 & 4.8977 \\
\hline
\end{tabular}




\begin{tabular}{|c|c|c|c|c|}
\hline $\begin{array}{c}\text { Actual } \\
\text { distance(m) }\end{array}$ & 15 & 30 & 60 & 90 \\
\hline $\begin{array}{c}\text { Max. } \\
\text { equivalent } \\
\text { elastic strain } \\
(\mathbf{m m} / \mathbf{m m})\end{array}$ & $\begin{array}{l}1.0175 \times \\
10^{-2}\end{array}$ & $\begin{array}{l}1.0271 \times \\
10^{-3}\end{array}$ & $2.2727 \times 10^{-4}$ & $1.1701 \times 10^{-4}$ \\
\hline $\begin{array}{c}\text { Min. } \\
\text { equivalent } \\
\text { elastic } \\
\text { strain }(\mathbf{m m} / \mathbf{m m})\end{array}$ & $\begin{array}{l}2.5022 \times \\
10^{-3}\end{array}$ & $\begin{array}{l}2.5257 \times \\
10^{-4}\end{array}$ & $5.5889 \times 10^{-5}$ & $2.8775 \times 10^{-5}$ \\
\hline $\begin{array}{c}\text { Max. } \\
\text { principal elastic } \\
\text { strain }(\mathbf{m m} / \mathbf{m m})\end{array}$ & $\begin{array}{l}6.2783 \times \\
10^{-3}\end{array}$ & $\begin{array}{l}6.3373 \times \\
10^{-4}\end{array}$ & $1.4023 \times 10^{-4}$ & $7.2199 \times 10^{-5}$ \\
\hline $\begin{array}{c}\text { Min. } \\
\text { principal elastic } \\
\text { strain } \\
(\mathbf{m m} / \mathbf{m m}) \\
\end{array}$ & $\begin{array}{l}4.3606 \times \\
10^{-4}\end{array}$ & $\begin{array}{l}4.4016 \times \\
10^{-5}\end{array}$ & $9.7397 \times 10^{-6}$ & $5.0146 \times 10^{-6}$ \\
\hline $\begin{array}{c}\text { Max. } \\
\text { equivalent stress } \\
\text { (MPa) }\end{array}$ & 289.99 & 29.271 & 6.477 & 3.3348 \\
\hline $\begin{array}{c}\text { Min. } \\
\text { equivalent } \\
\text { stress(MPa) }\end{array}$ & 57.818 & 5.8362 & 1.2914 & 0.6649 \\
\hline $\begin{array}{c}\text { Max. } \\
\text { principal stress } \\
(\mathrm{MPa})\end{array}$ & 183.41 & 18.513 & 4.0695 & 2.1091 \\
\hline $\begin{array}{c}\text { Min. } \\
\text { principal } \\
\text { stress(MPa) }\end{array}$ & -3.4816 & -0.3514 & -0.0777 & -0.0400 \\
\hline
\end{tabular}

\section{Conclusion}

As the cooling tower is an important part of the power plant it is connected with so many processes and loads. In this paper analysis of blast load on cooling tower has been carried out. Conclusions derived from the analysis are:

Total deformation, stresses and strains of the structure are decreases with increase in distance of the explosion from the structure.

Max equivalent elastic strain in case of $15 \mathrm{~m}$ distance is 0.01075 which exceeds the max permissible limit of strain 0.0035 as given in IS 456:2000. The same is within permissible limit for $30 \mathrm{~m}, 60 \mathrm{~m}$ and $90 \mathrm{~m}$.

Value of total deformation of the structure is $425.89 \mathrm{~mm}$ which exceeds the limiting value 275.94 $\mathrm{mm}$ as per IS 456:2000.

The von misses stress for $15 \mathrm{~m}$ distance of explosion is $289.99 \mathrm{MPa}$ which is higher compared to permissible stress of concrete and steel. For 30m, 60m and 90m distances stresses are within the limit.

Form these, we can conclude that, till $15 \mathrm{~m}$ area around the hyperbolic cooling tower is required good safety measures as it is nearest distance and highly affected by the blast load. 


\section{References}

IS 4991 (1968). Criteria for blast resistant design of structures for explosion of above ground.

He, S. (2015). Performance improvement of natural dry draft cooling tower using wetted medium evaporated pre cooling. Australia: the unisversitry of queensland.

Nitesh, M. (2009). Prediction of blast loading and its impact on building. Rourkela: National institute of Technology.

Sigmund, H. D. (2012). Blast loading on structures. technicki Vjesnik. 